\title{
The local displacement of a sexually reproducing ostracod by a conspecific parthenogen
}

\author{
J. A. CHAPLIN* \\ Department of Biology, University of Wollongong, Wollongong, NSW, 2500, Australia
}

\begin{abstract}
Candonocypris novaezelandiae is a freshwater ostracod which can perhaps best be described as a species complex of sexual and parthenogenetic forms of each of two morphs. Genetically distinct sexual and parthenogenetic forms of one of these morphs (the small-brown morph) coexist in a large maar lake in south-eastern Australia. Repeated sampling has revealed that the sex ratio of the small-brown morph in this lake is highly significantly biased in favour of females and that, during a 27 month sampling period, the extent of this bias increased consistently from 2.76 females per male in the first sample to 6.9 females per male in the final sample. Associated with the increase in the relative abundance of females was a reduction in the level of multi-locus genotypic diversity relative to expectations for sexual reproduction and recruitment. The initial sample displayed 92 per cent of the multi-locus genotypic diversity expected for a sample from a population with the same underlying genetic composition but which relies exclusively upon sexually generated recruitment; only 50 per cent of the expected diversity was observed for the final sample. These sex ratio and diversity changes are consistent with an increase in the relative abundance of parthenogenetic females in this population. This interpretation is supported by the finding that during the sampling period the relative abundance of four putative clonal genotypes in samples increased from 3.8 to 29.41 per cent. The displacement of a sexual lineage by a closely related parthenogenetic form in a spatially heterogeneous, biotically diverse environment, such as that sampled, is at odds with theoretical predictions about the ecological and evolutionary roles of sexual reproduction but may be related to an increase in the degree of human disturbance of the lake habitat (or at least of the sampling site). In contrast to the lake population in which the sexual lineage appears, at least for the time being, to be numerically dominant, populations of this ostracod in two artificial farm ponds located within close proximity to the lake had a highly clonal structure.
\end{abstract}

Keywords: freshwater Ostracoda, parthenogenesis, population structure, sexual reproduction.

\section{Introduction}

Animal species which include sympatric sexually and asexually reproducing forms appear to be relatively rare, although this must be partly a consequence of the lack of study of many taxa and of the difficulty in detecting different reproductive types within single habitats, especially if one type is relatively rare (see Bell, 1982). Nonetheless, there are several known examples of such sympatric associations but in most of these cases it is not clear whether or not the coexistence of the two reproductive forms is transient or

*Present address: Department of Zoology, University of Guelph, Guelph, Ontario, Canada, N1G 2W1.

Contribution number 104 from the Ecology and Genetics Group at the University of Wollongong. stable (Lynch, 1984). Many theoretical models predict that, except in spatially heterogeneous or biotically diverse environments, such associations will be transient and that the asexually reproducing form will completely displace the sexual lineage (see Williams, 1975; Maynard Smith, 1978; Bell, 1982; Stearns, 1987; Michod \& Levin, 1988).

The freshwater Ostracoda are thought to include a small number of species which have the capacity for both sexual and asexual modes of reproduction (Chaplin, 1992). Conspecific sexual and asexual forms of ostracod are generally believed to comprise distinct lineages and, with but one exception, the different reproductive forms of single species have been recorded only from different geographical regions or at least from different water bodies (Bell, 1982; Brohn- 
stein, 1988; Chaplin, 1992). The breeding systems of ostracod species with a variable mode of reproduction are, however, very poorly studied and it is likely more than coincidental that the only good evidence of an ostracod population which includes both sexual and asexual forms pertains to the only such species for which there is detailed information on its breeding system. This is the Australasian species Candonocypris novaezelandiae (see Chaplin \& Ayre, 1989; Chaplin, 1991, 1992).

C. novaezelandiae is probably a species complex which includes two morphologically and genetically distinct species, each of which in turn comprises sexual and asexual forms (Chaplin, 1991, 1992). In one of these morphs (species?) (the large-green morph), populations appear to consist exclusively of either parthenogenetic females or of sexual females and males (Chaplin, 1992). In addition, contrasting modes of reproduction for this morph have, so far, been confirmed only for genetically distinct individuals collected from locations more than $3500 \mathrm{~km}$ apart (Chaplin, 1991). The two reproductive forms of the other morph (species?) (the small-brown morph) are also genetically distinct but co-occur in at least one location. The results of a series of laboratory breeding trials indicate that a population of this morph in Lake Purrumbete in south-eastern Australia consists of a numerically dominant sexual form as well as a genetically distinct parthenogenetic form (Chaplin, 1992), although this interpretation has not yet been confirmed using information on patterns and levels of genotypic variation within this population. A parthenogenetic lineage of the large-green morph also occurs in the lake but is relatively rare (Chaplin, 1992).

In support of the interpretation that the population of the small-brown morph in Lake Purrumbete includes both a sexual and a parthenogenetic lineage, is the fact that, although males are present, the sex ratio of this population is highly significantly biased in favour of females (Chaplin, 1992). Moreover, the extent of this female bias appears to be steadily increasing with time (Chaplin, 1992). This might indicate that the relative abundance of the parthenogens in this population is increasing. However, the basis for the female bias and associated temporal changes could be interpreted in other ways. Large excesses of females are common in mixed-sex populations of ostracods. This is true even of populations for which their exclusive reliance upon sexual reproduction has been verified with allozyme data (Havel et al., 1990). Although the basis for these excesses of females has not been investigated experimentally for any species, it is often explained in terms of reduced longevity and sometimes reduced vitality of males (McKenzie, 1971; Tetart,
1975; Harten, 1983). The observed increase in the female bias of the sex ratio of the population of the small-brown morph in Lake Purrumbete might simply reflect environmental changes which have favoured the survival of sexual females relative to their male counterparts.

Other populations of the small-brown morph of $C$. novaezelandiae occur in artificial ponds on farms in the immediate vicinity of Lake Purrumbete (and elsewhere). Unlike those from Lake Purrumbete, samples collected from these populations did not contain any males (Chaplin, 1991), indicating that these populations might be maintained exclusively by parthenogenetic reproduction and recruitment. Moreover, given that the population in Lake Purrumbete was probably originally exclusively sexual (Chaplin, 1991), it is possible that one or more of these pond populations are the original source of the clones that are now present in the lake. However, currently there are no data on the clonal composition of any of these populations.

The primary aim of this study was to compare patterns and levels of genotypic diversity within multiple samples of the small-brown morph of $C$. novaezelandiae collected from Lake Purrumbete between December 1988 and March 1991. This information was used to: (i) confirm that within Lake Purrumbete this morph is predominantly dependent on sexual reproduction and recruitment but also includes a parthenogenetic lineage; and (ii) test the prediction that the relative abundance of the parthenogenetic lineage has increased during the sampling period. A secondary aim was to use patterns of allozyme variation to: (i) determine if two apparently all-female populations nearby to Lake Purrumbete have a clonal structure; and (ii) compare the clonal diversity and composition of these populations with that of the small-brown morph in Lake Purrumbete.

\section{Materials and methods}

\section{Collection of specimens}

Mixed-sex population in Lake Purrumbete. Samples of males and females of the small-brown morph of $C$. novaezelandiae were collected from Lake Purrumbete in southern Victoria, Australia $\left(143^{\circ} 14^{\prime} \mathrm{E}, 38^{\circ} 17^{\prime} \mathrm{S}\right)$ on the following five occasions: December 1988; April 1989; July 1989; February 1990; and March 1991. These samples were collected from the benthos of the lake using a hand net. On each sampling occasion, ostracods were collected from the same relatively small 
(less than $5 \mathrm{~m}^{2}$ in area) patch of habitat. This patch is located in the littoral zone of the lake.

At least by Australian standards, Lake Purrumbete is a large, deep body of freshwater (surface area $=552$ ha, maximum diameter $=3.21 \mathrm{~km}$, maximum depth $=45$ m (De Deckker \& Williams, 1988)). It is a maar (volcanic) lake which has suffered relatively little from human-related disturbances, although it is regularly stocked with and fished for exotic fish. Compared to typical pond environments, the lake comprises a large number of habitat types (i.e. is relatively spatially heterogeneous) and contains a species-rich benthos (see Timms, 1980a,b).

All-female populations in farm ponds. Samples of the small-brown morph of $C$. novaezelandiae were collected on five separate occasions between December 1988 and March 1991 from two apparently all-female populations in artificial farm ponds located within $1 \mathrm{~km}$ (population code CD6; $143^{\circ} 15^{\prime} \mathrm{E}$, $38^{\circ} 18^{\prime} \mathrm{S}$ ) and $5 \mathrm{~km}$ (population code CD3; $143^{\circ} 08^{\prime} \mathrm{E}$, $38^{\circ} 18^{\prime} \mathrm{S}$ ) of Lake Purrumbete. As was the case for the Lake Purrumbete samples, a hand net was used to collect ostracods from the benthos of these water bodies from a sampling site less than $5 \mathrm{~m}^{2}$ in area.

These farm ponds were much smaller and shallower than Lake Purrumbete (both were less than $30 \mathrm{~m}$ in maximum diameter and $2 \mathrm{~m}$ in maximum depth) and displayed many fewer habitat types (i.e. were relatively spatially homogeneous).

\section{Sorting of samples}

Samples were sorted at a magnification of $\times 25$ using a dissecting microscope to identify specimens of the small-brown morph of $C$. novaezelandiae and to determine their sex ratios. Identification and determination of the gender of specimens were done using the criteria outlined in Chaplin (1991, 1992). Sorted (sexed) specimens from the December 1988, February 1990 and March 1991 lake samples and from the March 1991 pond samples were then frozen at $-80^{\circ} \mathrm{C}$ and a subset of these were later processed for electrophoretic analysis.

\section{Electrophoresis}

Horizontal starch-gel electrophoresis was used to infer the genotypes of individual ostracods for up to four enzyme-encoding loci. The enzymes assayed were arginine phosphokinase (APK, EC: 2.7.3.3), mannose phosphate isomerase (MPI, EC: 5.3.1.8); phosphoglucomutase (PGM, EC: 2.7.5.1) and phosphoglucose isomerase (GPI, EC: 5.3.9.1). These four enzymes were selected because previous studies showed them to display scorable polymorphisms within $C$. novaezelandiae (see Chaplin, 1991). Electrophoretic procedures and buffers, and interpretation of zymograms were as described in Chaplin \& Ayre (1989) and Chaplin (1992). The only exception to this was that, because additional alleles have since been discovered for the $C$. novaezelandiae complex, some of the allele designations have been changed (see Table 1). Specimens from the pond populations were each assayed for all four enzymes and were each then assigned a four-locus genotype. The specimens in the first and final samples from Lake Purrumbete were similarly treated except that each was assayed and assigned a genotype for $G p i$, $P g m$ and $M p i$ only. For the February 1990 sample from Lake Purrumbete, only the MPI polymorphism was scored.

\section{Data analyses}

The temporal stability of the coexistence of the sexual and asexual forms within Lake Purrumbete was assessed by comparing the contribution of sexual reproduction to three temporally isolated samples from this population. The contribution of sexual reproduction to first and final of these samples, and to each of the final (March 1991) samples from the pond populations, was estimated by comparing: (i) the number of distinct multi-locus genotypes present within each sample $\left(\mathrm{N}_{\mathrm{g}}\right)$ to the number expected for a sample with the same underlying gene frequencies and

Table 1 Comparison of the designations used in this study to identify alleles of the small-brown morph of

Candonocypris novaezelandiae with those used in a previous study (Chaplin, 1992) to identify putatively identical alleles. The designations used for $A p k$ alleles were the same in both studies

\begin{tabular}{|c|c|c|}
\hline \multirow[b]{2}{*}{ Locus } & \multicolumn{2}{|c|}{ Allelic designations } \\
\hline & Chaplin 1992 & This study \\
\hline \multirow[t]{4}{*}{$G p i$} & $\mathrm{~b}$ & c \\
\hline & $\mathrm{d}$ & $\mathrm{e}$ \\
\hline & $\mathrm{e}$ & f \\
\hline & $f$ & $\mathrm{~h}$ \\
\hline \multirow[t]{3}{*}{ Pgm } & $\mathrm{a}$ & b \\
\hline & b & $\mathrm{c}$ \\
\hline & $\mathrm{c}$ & $\mathrm{d}$ \\
\hline \multirow[t]{3}{*}{$M p i$} & $\mathrm{a}$ & $\mathrm{a}$ \\
\hline & $\mathrm{c}$ & $\mathrm{c}$ \\
\hline & $\mathrm{e}$ & d \\
\hline
\end{tabular}


generated exclusively by sexual reproduction $\left(\mathrm{N}_{\mathrm{e}}\right)$; and (ii) the level of genotypic diversity observed for each sample $\left(G_{0}\right)$ to the level expected for a genetically equivalent, sexually generated sample $\left(G_{e}\right)$. The proportion of parthenogens in the other Lake Purrumbete sample was estimated on the basis of the frequency of particular $M p i$ genotypes thought to be diagnostic of these individuals. $G_{0}$ was calculated as $1 / \Sigma \mathrm{g}_{i}^{2}$, where $\mathrm{g}_{i}$ is the frequency of the ith genotype and thus takes into account the evenness component of diversity (i.e. the distribution of individuals among genotypes) as well as the contribution of the number of genotypes (Stoddart, 1983). $\mathrm{N}_{\mathrm{e}}$ and $\mathrm{G}_{\mathrm{c}}$ were calculated using the method described in Stoddart \& Taylor (1988). In samples generated exclusively by sexual reproduction, $\mathrm{N}_{\mathrm{g}}$ should approach or equal $\mathrm{N}_{\mathrm{e}}$. Similarly, for such samples $G_{o}$ is expected to be statistically equivalent to $G_{c}$. The statistical significance of any observed departures of $G_{0}$ from $G_{e}$ was assessed using a $t$-test which incorporated the variance estimate developed by Stoddart \& Taylor. Since this study aimed to determine the basis for changes in the female bias of the sex ratio of samples from Lake Purrumbete, and since males of $C$. novaezelandiae are hemizygous for the Pgm locus (Chaplin, 1992) (which precludes calculation of $\mathrm{N}_{e}$ and $\mathrm{G}_{\mathrm{e}}$ combined for both sexes), only females were compared between the first and final Lake Purrumbete samples.

To further assess the influence of asexual reproduction on samples from the pond populations, singlelocus genotype frequencies observed for these samples were tested for departures from the frequencies expected under conditions of Hardy-Weinberg equilibrium. The magnitude of such departures was assessed as $\mathrm{D}=\left(\mathrm{H}_{\mathrm{o}}-\mathrm{H}_{\mathrm{e}}\right) / \mathrm{H}_{\mathrm{e}}$, where $\mathrm{H}_{\mathrm{o}}$ and $\mathrm{H}_{\mathrm{e}}$ are, respectively, the total numbers of observed and expected heterozygotes at each locus (Curie-Cohen, 1982). The statistical significance of departures of the total number of observed heterozygotes from the number expected under conditions of Hardy-Weinberg equilibrium was assessed using chi-square goodness-of-fit tests. The recruitment of asexually derived larvae within populations may result in significant excesses or deficits of heterozygotes, although excesses of heterozygotes provide particularly strong evidence of such recruitment (Chaplin \& Ayre, 1989).

\section{Results}

\section{Mixed-sex population in Lake Purrumbete}

Sex ratio. As was reported in Chaplin (1992), all five samples from the population of the small-brown morph of $C$. novaezelandiae in Lake Purrumbete

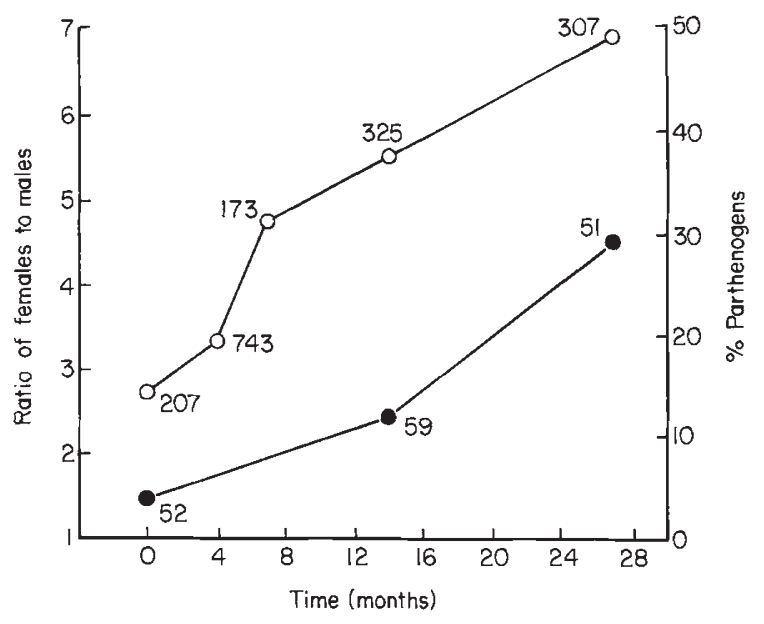

Fig. 1 Changes in the sex ratio and proportion of parthenogens (clonal genotypes) among temporally isolated samples of the small-brown morph of Candonocypris novaezelandiae from Lake Purrumbete. Sex ratio data - (0); \% parthenogens - $\bullet$; time $0=$ December 1988 . Sample sizes are indicated adjacent to the corresponding data points.

included both males and females but had a sex ratio highly biased in favour of females (Chi-square, $P<0.001)$. The extent of this female bias increased consistently from 2.76 females per male in the first sample to 6.9 females per male in the final sample (Fig. 1).

Patterns and levels of genotypic diversity. A relatively high number of distinct multi-locus genotypes (a minimum of 21) and individuals with a unique such genotype (at least 21 per cent) were detected among females from each of the first and final samples of the smallbrown morph from Lake Purrumbete (Table 2). Similarly high levels of genotypic diversity and unique genotypes were found among males from the first sample (Table 3). This was true even though only three loci, including one which was only marginally variable (Mpi), were assayed. These findings, together with the presence of males in all samples, indicate that there is a substantial input of sexually derived recruitment into the small-brown morph in Lake Purrumbete.

Patterns of allozyme variation show that the increase in the female-bias of samples has been accompanied by a large reduction in the level of multi-locus genotypic diversity relative to expectations for sexual reproduction. Both the number of multi-locus genotypes $\left(\mathrm{N}_{\mathrm{g}}\right)$ and the multi-locus genotypic diversity $\left(\mathrm{G}_{\mathrm{o}}\right)$ detected in the initial sample of females approached expectations for sexual reproduction with random mating and freerecombination (Table 2). In contrast, in the final sample, $\mathrm{N}_{\mathrm{g}}$ had decreased to 43 per cent of the value 
Table 2 Number of individuals with each of 33 three-locus genotypes detected within the first (December 1988) and final (March 1991) samples of N small-brown females of Candonocypris novaezelandiae from the mixed-sex population in Lake Purrumbete. The four putative clonal lineages found within these predominantly sexual samples are marked with a ' $t$ '. The number of distinct multi-locus genotypes detected within each sample $\left(\mathrm{N}_{g}\right)$ and the number of such expected for samples from a strictly sexual population $\left(\mathrm{N}_{\mathrm{e}}\right)$ are compared both for entire samples and for these same samples minus the clonal genotypes. Similarly, the observed level of multi-locus genotypic diversity is compared with the level expected for samples from a strictly sexual population $\left(G_{0}: G_{e}\right)$ for both of these samples states. $P$ is the probability that the value of $G_{0}: G_{e}$ is not significantly different from one

\begin{tabular}{|c|c|c|c|c|c|}
\hline \multirow{2}{*}{$\begin{array}{l}\text { Genotype } \\
\text { number }\end{array}$} & \multicolumn{3}{|c|}{$\begin{array}{l}\text { Genotype } \\
\text { Enzyme locus }\end{array}$} & \multirow{2}{*}{$\begin{array}{l}\text { Dec. } \\
1988 \\
\text { sample }\end{array}$} & \multirow{2}{*}{$\begin{array}{l}\text { March } \\
1991 \\
\text { sample }\end{array}$} \\
\hline & Gpi & Pgm & $M p i$ & & \\
\hline 1 & $\mathrm{cc}$ & cc & dd & 10 & 6 \\
\hline 2 & ce & $\mathrm{cc}$ & $\mathrm{dd}$ & 5 & 1 \\
\hline 3 & ce & $\mathrm{bc}$ & $\mathrm{dd}$ & 5 & 1 \\
\hline 4 & $\mathrm{cc}$ & $\mathrm{bb}$ & $\mathrm{dd}$ & 4 & - \\
\hline 5 & $\mathrm{cf}$ & $\mathrm{cc}$ & $\mathrm{dd}$ & 4 & 3 \\
\hline 6 & cc & $\mathrm{cd}$ & $\mathrm{dd}$ & 3 & 1 \\
\hline 7 & $\mathrm{cc}$ & bc & dd & 3 & 6 \\
\hline 8 & ch & bc & $\mathrm{dd}$ & 3 & 1 \\
\hline 9 & ce & $\mathrm{cd}$ & dd & 2 & 1 \\
\hline 10 & $\mathrm{cc}$ & $\mathrm{bc}$ & $\mathrm{dd}$ & 1 & 2 \\
\hline 11 & ce & $\mathrm{dd}$ & $\mathrm{dd}$ & 1 & - \\
\hline 12 & cf & $\mathrm{cd}$ & $\mathrm{dd}$ & 1 & - \\
\hline 13 & cf & bc & $\mathrm{dd}$ & 1 & 2 \\
\hline 14 & ch & bb & $\mathrm{dd}$ & 1 & - \\
\hline 15 & ee & $\mathrm{bc}$ & $\mathrm{dd}$ & 1 & - \\
\hline 16 & ef & $\mathrm{cc}$ & $\mathrm{dd}$ & 1 & - \\
\hline 17 & eh & $\mathrm{bc}$ & $\mathrm{dd}$ & 1 & - \\
\hline 18 & ei & $\mathrm{bc}$ & dd & 1 & - \\
\hline 19 & ff & $\mathrm{cc}$ & dd & 1 & - \\
\hline 20 & $\mathrm{ff}$ & $\mathrm{bc}$ & dd & 1 & - \\
\hline 21 & cc & $\mathrm{dd}$ & $\mathrm{dd}$ & - & 3 \\
\hline 22 & ce & bb & $\mathrm{dd}$ & - & 2 \\
\hline 23 & $\mathrm{ch}$ & $\mathrm{cd}$ & dd & - & 1 \\
\hline 24 & ch & $\mathrm{cc}$ & dd & - & 1 \\
\hline 25 & ci & $\mathrm{cc}$ & $\mathrm{dd}$ & - & 1 \\
\hline 26 & $\mathrm{ff}$ & bd & $\mathrm{dd}$ & - & 1 \\
\hline 27 & ff & dd & dd & - & 1 \\
\hline 28 & hh & $\mathrm{bb}$ & dd & - & 1 \\
\hline 29 & hh & $\mathrm{cc}$ & $\mathrm{dd}$ & - & 1 \\
\hline $30 \dagger$ & ee & $\mathrm{dd}$ & $\mathrm{cc}$ & 2 & 7 \\
\hline $31 \dagger$ & $\mathrm{cc}$ & bd & $\mathrm{cc}$ & - & 4 \\
\hline $32 \dagger$ & ee & dd & ac & - & 3 \\
\hline $33 \dagger$ & ce & dd & ad & - & 1 \\
\hline \multicolumn{6}{|c|}{ (entire sample) } \\
\hline \multicolumn{4}{|c|}{$\mathrm{N}$} & 52 & 51 \\
\hline \multicolumn{4}{|c|}{$\mathrm{N}_{\mathrm{g}}$} & 21 & 23 \\
\hline \multicolumn{4}{|l|}{$\mathrm{N}_{\mathrm{e}}^{\mathrm{g}}$} & 23 & 54 \\
\hline
\end{tabular}

Table 2 Continued

\begin{tabular}{|c|c|c|c|c|c|}
\hline \multirow{2}{*}{$\begin{array}{l}\text { Genotype } \\
\text { number }\end{array}$} & \multicolumn{3}{|c|}{$\begin{array}{l}\text { Genotype } \\
\text { Enzyme locus }\end{array}$} & \multirow{2}{*}{$\begin{array}{l}\text { Dec. } \\
1988 \\
\text { sample }\end{array}$} & \multirow{2}{*}{$\begin{array}{l}\text { March } \\
1991 \\
\text { sample }\end{array}$} \\
\hline & Gpi & Pgm & $M p i$ & & \\
\hline $\mathrm{G}_{\mathrm{o}}$ & & & & 11.90 & 13.76 \\
\hline $\mathrm{G}_{\mathrm{o}}: \mathrm{G}_{\mathrm{e}}$ & & & & 0.92 & 0.50 \\
\hline$P$ & & & & & \\
\hline \multicolumn{6}{|c|}{ (without clonal genotypes) } \\
\hline $\mathrm{N}$ & & & & 50 & 36 \\
\hline $\mathrm{N}_{\mathrm{g}}$ & & & & 20 & 19 \\
\hline $\mathrm{N}_{\mathrm{e}}^{\mathrm{g}}$ & & & & 19 & 17 \\
\hline $\mathrm{G}_{0}$ & & & & 11.16 & 11.37 \\
\hline $\mathrm{G}_{\mathrm{o}}: \mathrm{G}_{\mathrm{e}}$ & & & & 1.10 & 1.05 \\
\hline$P$ & & & & ns & ns \\
\hline
\end{tabular}

ns $P>0.05$, no significant difference; ${ }^{*} 0.05>P>0.01$; *** $P<0.001$.

Table 3 Number of individuals with each of 15 three-locus genotypes, the total number of distinct three-locus genotypes $\left(\mathrm{N}_{\mathrm{g}}\right)$, and the level of multi-locus genotypic diversity $\left(\mathrm{G}_{\mathrm{o}}\right)$ detected for a sample of $\mathrm{N}$ male individuals of the smallbrown morph of Candonocypris novaezelandiae from Lake Purrumbete. Note that these males are hemizygous for Pgm

\begin{tabular}{|c|c|c|c|c|}
\hline \multirow{2}{*}{$\begin{array}{l}\text { Genotype } \\
\text { number }\end{array}$} & \multicolumn{3}{|c|}{$\begin{array}{l}\text { Genotype } \\
\text { Enzyme locus }\end{array}$} & \multirow{2}{*}{$\begin{array}{l}\text { Number of } \\
\text { individuals }\end{array}$} \\
\hline & $G p i$ & $P g m$ & $M p i$ & \\
\hline 1 & $\mathrm{cc}$ & $c$ & dd & 8 \\
\hline 2 & $\mathrm{cc}$ & $b$ & $\mathrm{dd}$ & 5 \\
\hline 3 & $\mathrm{ce}$ & b & $\mathrm{dd}$ & 4 \\
\hline 4 & cf & c & dd & 3 \\
\hline 5 & $\mathrm{ce}$ & $\mathrm{c}$ & $\mathrm{dd}$ & 2 \\
\hline 6 & ch & b & $\mathrm{dd}$ & 2 \\
\hline 7 & $\mathrm{cc}$ & d & dd & 1 \\
\hline 8 & ee & d & $\mathrm{dd}$ & 1 \\
\hline 9 & ee & c & $\mathrm{dd}$ & 1 \\
\hline 10 & ef & $\mathrm{b}$ & $\mathrm{dd}$ & 1 \\
\hline 11 & ci & $\mathrm{b}$ & $\mathrm{dd}$ & 1 \\
\hline 12 & ci & c & $\mathrm{dd}$ & 1 \\
\hline 13 & $\mathrm{ch}$ & $\mathrm{c}$ & $\mathrm{dd}$ & 1 \\
\hline 14 & $\mathrm{cf}$ & $\mathrm{d}$ & $\mathrm{dd}$ & 1 \\
\hline 15 & ei & $c$ & dd & 1 \\
\hline $\mathrm{N}$ & & & & 33 \\
\hline $\mathrm{N}_{\mathrm{g}}$ & & & & 15 \\
\hline $\mathrm{G}_{0}^{\mathrm{g}}$ & & & & 8.31 \\
\hline
\end{tabular}

expected for sexual reproduction, and $\mathrm{G}_{\mathrm{o}}$ was reduced to half of the expected value (Table 2). These sex ratio and genetic data provide strong evidence of an increase throughout the sampling period in the relative propor- 
tion of asexually derived females present within the Lake Purrumbete samples of the small-brown morph.

Three of the 23 three-locus genotypes detected from the final sample from Lake Purrumbete probably represent clonal lineages (genotype numbers 30, 31 and 32 in Table 2). These genotypes included distinctive alleles at $M p i$ and represented non-random multilocus associations. $M p i^{c c}$ was, for example, represented by 11 individuals but always in association with either multi-locus genotypes 30 or 31 (Table 2). Similarly, $M p i^{a c}$ was exclusively associated with the three representatives of genotype 32 (Table 2). A random combination of the alleles detected would have been highly unlikely to generate any of these three multilocus associations more than once in a sample of 51 individuals. The distinctiveness of these genotypes is further illustrated by the absence of any of the 17 'cd' heterozygotes expected at $M p i$ under conditions of Hardy-Weinberg equilibrium.

There are a number of observations which support the interpretation that genotypes 30, 31 and 32 represent clonal groups. These are that: (i) $\mathrm{Mpi}^{i c}$ was also associated with genotype 30 in the first sample from Lake Purrumbete (Table 2); (ii) genotype 31 was identical to that of a small-brown parthenogenetic female from Lake Purrumbete which reproduced by parthenogenesis in laboratory breeding trials (see Chaplin 1992, but allow for the changes in allelic designations as indicated in Table 1); (iii) representatives of genotypes 30 and 31 from Lake Purrumbete have been shown to be, in common with parthenogenetic females of the small-brown morph of $C$. novaezelandiae from other populations, relatively large compared with putative sexual females (Chaplin, 1991); (iv) 33 males from the December 1988 sample from Lake Purrumbete were all monomorphic for $M^{\prime d}$ (Table 3), as were all male and female individuals for which breeding trials have confirmed a sexual mode of reproduction (Chaplin, 1991); (v) allele frequencies for both Gpi and Pgm were similar for male and female individuals which were homozygous for $M p i^{d}$ but were very different from those detected for individuals which were not homozygous for $M p i^{i}$ (see Tables 2 and 3 from which allele frequencies can be calculated); and (vi) genotypes 30 and 31 have been found in samples from clonal populations whereas individuals homozygous for $\mathrm{Mpi}^{d}$ have not (Table 4). Although genotype 33 was represented by a single female in the Lake Purrumbete samples, it is probably also a clonal genotype. This is suspected on the basis that it is not homozygous for $M p i^{d}$ (Table 2) and is represented in at least one clonal population (Table 4).

The extent to which diversity in the first, and especially in the final, Lake Purrumbete samples was
Table 4 Distribution of individuals among the three fourlocus genotypes detected within samples of $\mathrm{N}$ individuals of the small-brown morph of Candonocypris novaezelandiae from two all-female populations in farm ponds located nearby to Lake Purrumbete. The contribution of asexual reproduction to these samples is assessed by comparing the number of distinct four-locus genotypes detected $\left(\mathrm{N}_{\mathrm{g}}\right)$ to the number expected for sexual repoduction $\left(\mathrm{N}_{\mathrm{e}}\right)$ and by comparing the observed level of genotypic diversity of each sample to that expected for strictly sexual reproduction $\left(\mathrm{G}_{\mathrm{o}}: \mathrm{G}_{\mathrm{e}}\right) \cdot P$ is the probability that $\mathrm{G}_{\mathrm{o}}: \mathrm{G}_{\mathrm{e}}$ is not significantly different from a value of one

\begin{tabular}{|c|c|c|c|c|c|c|}
\hline \multirow{2}{*}{$\begin{array}{l}\text { Genotype } \\
\text { numbert }\end{array}$} & \multicolumn{4}{|c|}{$\begin{array}{l}\text { Genotype } \\
\text { Enzyme locus }\end{array}$} & \multicolumn{2}{|c|}{ Population } \\
\hline & $G p i$ & Apk & $P g m$ & $M p i$ & CD3 & CD6 \\
\hline $1(31)$ & $c c$ & $b c$ & bd & $c c$ & 9 & 14 \\
\hline $2(33)$ & $\mathrm{ce}$ & $b c$ & $\mathrm{dd}$ & $\mathrm{ad}$ & - & 25 \\
\hline $3(30)$ & ee & $b c$ & dd & $\mathrm{cc}$ & 15 & 1 \\
\hline$N$ & & & & & 24 & 40 \\
\hline $\mathrm{N}_{\mathrm{g}}$ & & & & & 2 & 3 \\
\hline$N_{e}^{g}$ & & & & & 12 & 30 \\
\hline $\mathrm{G}_{0}$ & & & & & 1.88 & 1.95 \\
\hline $\mathrm{G}_{\mathrm{o}}: \mathrm{G}_{\mathrm{e}}$ & & & & & 0.22 & 0.08 \\
\hline $\mathrm{P}$ & & & & & $* * *$ & $* * *$ \\
\hline
\end{tabular}

$* * * P<0.001$.

$\dagger$ In parentheses: the number used to identify the same threelocus genotype in samples from Lake Purrumbete (see Table 2).

affected by the presence of the putative clonal genotypes (i.e. genotypes 30, 31, 32 and 33 in Table 2) can be assessed by excluding these genotypes from diversity calculations. Without them, both the number of multi-locus genotypes and the genotypic diversity displayed by both the first and final samples conforms with expectations for sexual reproduction (Table 2). This shows that their presence not only had a dramatic effect on diversity levels but also that $M p i^{d d}$ is probably characteristic of the sexual lineage in Lake Purrumbete.

If, as was claimed above, the proportion of parthenogenetic females in Lake Purrumbete has increased over the sampling period, then the frequency of clonal genotypes in samples should be greater the later their date of collection. As is illustrated by Fig. 1, this was in fact the case. Thus the relatively rapid increase of the parthenogens seems clear, but, nonetheless, the sexuals were numerically dominant in both the first and final samples. This dominance was reflected by the high level of genotypic diversity displayed by both of these samples. 
Table 5 Departures from Hardy-Weinberg equilibrium expectations for samples of $\mathrm{N}$ individuals of the small-brown morph of Candonocypris novaezelandiae from two all-female populations in farm ponds located nearby to Lake Purrumbete. Departures $(D$ values) are given for up to four loci per sample. $P$ is the probability that the observed number of heterozygotes is not significantly different from the expected number

\begin{tabular}{llllllllll}
\hline Population & $\mathrm{N}$ & Gpi & $P$ & $A p k$ & $P$ & $P g m$ & $P$ & $M p i$ & $P$ \\
\hline CD3 & 24 & -1.00 & $* * *$ & 1.00 & $* * *$ & 0.23 & $\mathrm{~ns}$ & - & - \\
CD6 & 40 & 0.39 & $*$ & 1.00 & $* * *$ & 0.21 & $\mathrm{~ns}$ & -0.02 & $\mathrm{~ns}$ \\
\hline
\end{tabular}

$\mathrm{Bar}(-)$ indicates fixation of allele at that locus (i.e. the frequency of the most common allele was $\geq 0.95$ ).

ns (not significant), $P>0.05 ;{ }^{*} 0.05>P>0.01 ;{ }^{* * *} P<0.001$.

\section{All-female populations in farm ponds}

The structure of the two sampled pond populations of the small-brown morph of $C$. novaezelandiae appears to be strikingly different to that of the Lake Purrumbete population and seems to reflect a much greater contribution of asexual reproduction to the former. Multiple samples from each of these pond populations each contained between 100 and 264 adult females but no males. Genetic analysis of a single sample from each pond population provides even stronger evidence of their reliance on asexual reproduction. Each of these samples showed a maximum of only two or three distinct four-locus genotypes; significant departures from Hardy-Weinberg equilibrium expectations for single locus genotype frequencies, including a highly significant excess of heterozygotes at one locus, and levels of genotypic diversity which were always highly significantly less than, and in one case less than 1 per cent of, the value expected for sexual reproduction (Tables 4 and 5).

\section{Discussion}

\section{Sexual and parthenogenetic lineages within Lake Purrumbete}

This study provides strong evidence in support of the suggestion by Chaplin (1992) that the population of the small-brown morph of $C$. novaezelandiae in Lake Purrumbete includes both sexual and parthenogenetic females which can be identified by their distinctive $M p i$ genotypes. Moreover, both types of female can be collected from small, seemingly homogeneous habitat patches and therefore coexist on a very local scale. Although the coexistence of sexual and parthenogenetic females within populations of Ostracoda has been suggested as being likely to occur (e.g. Bell, 1982;
Henderson, 1990; Chaplin, 1992), this is the first confirmed report of such an occurrence. Perhaps of even more importance is the evidence which suggests that this coexistence is temporally unstable. Specifically, the reduction in levels of multi-locus genotypic diversity relative to expectations for sexual reproduction (which appears to reflect an increase in the relative abundance of four clones (or clonal groups)), concomitant with an increase in the female-bias of the sex ratio, indicate that the abundance of parthenogenetic females of this ostracod in samples from Lake Purrumbete has been steadily increasing at the expense of sexual females and males for at least the 27 month duration of the sampling period. If the current trend continues, then the parthenogens will probably supplant the sexuals in the sampled habitat patch. The situation for the entire population may, however, be much more complex and to be resolved requires sampling at additional sites within the lake. If, however, the sampled habitat patch is representative of the population in general, then, contrary to some theoretical predictions (see Bell, 1982; Stearns, 1987; Michod \& Levin, 1988), this would be a situation of an asexual lineage displacing a closely-related sexual one in a spatially heterogeneous and biotically diverse environment.

Although the presence of parthenogenetic females, in addition to sexual ones, is an important source of the female-biased sex ratio of samples of the small-brown morph from Lake Purrumbete, the parthenogens do not appear to occur in sufficient numbers to explain the full extent of this bias. If, for example, the parthenogens account for 29.41 per cent of females in the final sample (as indicated by the frequency of individuals which were not homozygous for $M \mathbf{p i}^{d}$ ) then, even without the parthenogens, there were in this sample still 4.8 females for every male. Indeed, for the three lake samples which were assayed electrophoretically, either the proportion of parthenogens present must have 
been greatly underestimated or the number of sexual females present must have significantly exceeded the number of males. Given that the genetic data of both previous breeding trials (Chaplin, 1991, 1992) and this paper indicate that $M p i^{d d d}$ is a reliable indicator of the sexual lineage, it is likely that there is an excess of females even within the sexual lineage of the smallbrown morph. Such excesses may, in fact, be common within strictly sexual Ostracoda (Havel et al., 1990). In the case of the small-brown morph in Lake Purrumbete, the presence of parthenogens further increases the extent of the female bias of the sex ratio. These findings highlight the risks involved in using sex ratio data only to infer the breeding system of ostracods (as has largely happened in the past) since they show that large excesses of females may occur within strictly sexual lineages but also that the presence of males in populations does not necessarily indicate an exclusive reliance on sexual reproduction.

The association of the two reproductive types in Lake Purrumbete may be of relatively recent origin. In contrast to the results of this study, Hussainy (1969) found approximately equal numbers of males and females of the small-brown morph in this water body. Thus, at that time the population may have been exclusively sexual. Three of the four clonal genotypes detected from the lake samples of this study (i.e. genotypes 30,31 and 33 in Table 1) were also found in nearby parthenogenetic populations. These populations may have been the source of the clones in Lake Purrumbete. Indeed, during times of heavy rainfall, the CD6 pond, which contains all three of these 'clones', overflows into a stream system that then discharges into Lake Purrumbete. However, while this might provide a means by which the clones originally colonised Lake Purrumbete, it is unlikely to explain their apparent success relative to the sexuals. This is because $C$. novaezelandiae is a poor-swimming benthic inhabitant of lentic environments (De Deckker, 1981) and so is unlikely to be dispersed in large numbers of stream flow. Moreover, the inflow point of the stream system is some distance away from the sampling site.

The reason(s) for the apparent displacement of the sexual lineage by the parthenogens in Lake Purrumbete is not clear but may be related to the difference in their mode of reproduction. This difference is more likely to have had an effect if the sexual and parthenogenetic lineages compete for resources within the lake. The evidence that the two lineages do compete is that they show no signs of habitat segregation and compared to other lineages in the $C$. novaezelandiae complex, one of which also occurs in Lake Purrumbete, they show relatively little morphological and genetic divergence (see Chaplin, 1991). This evidence is, how- ever, weak and further study is required to determine the extent, if any, of competitive interactions between these two lineages. Nonetheless, at least in theory, there are a number of benefits associated with a parthenogenetic mode of reproduction which might provide the parthenogens with a short-term competitive advantage over the sexual lineage. These benefits include no cost of producing males (and thus a higher reproductive rate), the conservation of well adapted genotypes and, in most cases, a breeding system that promotes heterozygosity (see Williams, 1975; Bell, 1982; Stearns, 1987; Michod \& Levin, 1988; Hughes, 1989). Anyone or more of these considerations may be relevant in explaining the apparent accendancy of the small-brown parthenogens in Lake Purrumbete.

This study provides a rare account of the apparent displacement of a sexual lineage by closely related parthenogens. A superficially similar situation has been described for Daphnia pulex. In this species, obligate asexuality has spread through populations which originally reproduced by cyclical parthenogenesis via males of the obligate parthenogens transferring a meiotic-suppressor to cyclical parthenogenetic clones (Hebert et al., 1988). A possibly analogous situation occurs in the peach-potato aphid (see Blackman, 1981). In a model developed by Jaenike \& Selander (1979), sperm carrying a mutation that causes parthenogenetic egg development were shown to provide a viable mechanism for the spread of obligate asexuality in populations of sexually reproducing hermaphrodites. These authors suggested that such a mechanism might explain the high incidence of obligate parthenogenesis among oligochaetes, but thus far there is no direct evidence in support of their claim. The sperm-mediated spread of meiotic-suppressors is, however, unlikely to provide a general explanation for the origin and spread of obligate parthenogenesis because it requires parthenogens, at least in the shortterm, to retain the ability to produce normal sperm. Given that the all-female parthenogenetic lineage and the mixed-sex sexual lineage of $C$. novaezelandiae are genetically distinct, such an explanation cannot explain the spread of asexuality in this ostracod in Lake Purrumbete.

The apparent displacement of the sexual lineage by closely-related parthenogens in Lake Purrumbete is at odds with the expectations of some theorists. Despite the obvious short-term advantages of parthenogenesis, sexually reproducing forms are generally regarded as being competitively superior, except perhaps in spatially homogeneous or biologically depauperate environments (of which Lake Purrumbete is neither) (e.g. Cuellar, 1977; Glesener \& Tilman, 1978; Bell, 1982; Stearns, 1987; Michod \& Levin, 1988). There is, 
however, little direct evidence to support this view. In fact, considering the controversial nature of this issue, there have been surprisingly few experimental tests of the competitive outcome between closely related sexual and asexuals. Of the few such tests that have been conducted, the outcomes vary and are equivocal with respect to resolving the general issue (see Moore, 1975; Drosopoulos, 1977 (cited by Booij \& Guldemond, 1984); Lynch, 1984; Michaels \& Bazzaz, 1986; Browne \& Halanych, 1989). Indeed, they merely highlight the need for more experimental investigations. The situation of the small-brown morph of $C$. novaezelandiae in Lake Purrumbete provides an excellent opportunity for field and laboratory studies of competitive interactions within a sexual-asexual breeding complex.

\section{Two types of population structure}

This study has revealed two types of population structure within the small-brown morph of $C$. novaezelandiae. Samples from the pond populations were characterized by low levels of genotypic diversity, significant departures from Hardy-Weinberg expectations, including heterozygote excesses, and the absence of males. These characteristics strongly suggest that these populations are maintained by parthenogenetic reproduction (see Chaplin \& Ayre, 1989). In contrast, the presence of males and relatively high levels of genotypic diversity indicate that sexual reproduction and recruitment are of much greater importance to the population of the small-brown morph in Lake Purrumbete (although, as indicated above, this situation may be changing). On the basis that some of their populations include males whereas others apparently do not, several species of ostracod are thought to include two distinct types of population structure (see Chaplin, 1992). Prior to this study, however, genetic confirmation of such a condition was restricted to a single taxon - the large-green morph of C. novaezelandiae (see Chaplin \& Ayre 1989, but note that in this paper we did not specify as to which morph of $C$. novaezelandiae the results applied). For the large-green morph, so far, the different types of populations have been found only in different geographic locations (Chaplin, 1991). This study has not only documented two types of population structure for the small-brown morph of $C$. novaezelandiae but has shown that for this morph strictly parthenogenetic populations occur in the immediate vicinity of a predominantly, but not exclusively, sexual population.

Although both a parthenogenetic and a predominantly sexual population of the small-brown morph cooccur in the same general locality, the different types of population were found in different types of water body. The predominantly sexual population was found in a large maar (volcanic) lake, whereas two clonal populations (populations CD3 and CD6) and at least two other apparently exclusively female populations of this ostracod, occur in small, artificial farm ponds. This pattern seems to be similar to that observed for Old World populations of Artemia. For example, in one location, sexual and parthenogenetic populations of Artemia occur within several kilometres of each other: the parthenogenetic populations in man-made salterns, the sexual population in a natural saltern (see Browne \& MacDonald, 1982). These authors suggested that low biotic diversity, coupled with a physically controlled environment, may ultimately be responsible for the prevalence of parthenogenetic reproduction in the artificial salterns. These same environmental features are typical of farm ponds in Australia (Timms, 1980b) and may or may not explain the apparent dominance of parthenogenetic reproduction in the small-brown morph of $C$. novaezelandiae in such habitats. Such features cannot, however, account for the increase in the relative abundance of the parthenogens in Lake Purrumbete since neither are characteristic of this lake. In any case, for other sexual-asexual breeding complexes as well, sexual reproduction seems to be associated with relictal (relatively ancient natural) habitats (Bell, 1988; Hurst et al., 1992). For C. novaezelandiae in Lake Purrumbete, it is perhaps significant that the increase in the relative abundance of the parthenogens has at least partly coincided with the replacement of a boat jetty nearby to the sampling site (personal observation). The possible association between asexual reproduction in this ostracod and human-related environmental disturbance requires further investigation.

\section{Acknowledgements}

I am indebted to David Ayre for his seemingly neverending supply of patience, advice and insight. I thank Patrick De Deckker for his help with the taxonomy of C. novaezelandiae and for suggesting Lake Purrumbete as a possible study site. I am grateful to David Ayre and Julie Turgeon for their constructive criticism of an earlier version of this manuscript. The computer program used to calculate $\mathrm{G}_{\mathrm{e}}$ and $\mathrm{N}_{\mathrm{e}}$ was kindly provided by Jim Stoddart. The Murray-Darling Freshwater Research Centre and the University of Wollongong provided generous financial support.

\section{References}

BELL, G. 1982. The Masterpiece of Nature: the Evolution and Genetics of Sexuality. Croom Helm, London. 
BELL, G. 1988. Uniformity and diversity in the evolution of sex. In: Michod, R. E. and Levin, B. R. (eds) The Evolution of Sex: an Examination of Current Ideas, Sinauer Associates Inc, Massachusetts, pp. 126-138.

BLACKMAN, R. L. 1981. Species, sex and parthenogenesis in aphids. In: Forey, P. L. (ed.) The Evolving Biosphere, British Museum, London, pp. 75-85.

Bool, C. J. H. AND GULDEMOND, J. A. 1984. Distributional and ecological differentiation between asexual gynogenetic planthoppers and related sexual species of the genus Muellerianella (Homoptera, Delphacidae). Evolution, 38, 163-175.

BROHNSTEIN, Z. S. 1988. Fresh-water Ostracoda. Acad. Sci. USSR, Moscow.

BROWNE, R. A. AND HALANYCH, K. M. 1989. Competition between sexual and parthenogenetic Artemia: A re-evaluation (Branchiopoda, Anostraca). Crustaceana, 57, 57-71.

BROWNE, R. A. AND MACDONALD, G. H. 1982. Biogeography of the brine shrimp Artemia: Distribution of parthenogenetic and sexual populations. J. Biogeog., 9, 331-338.

CHAPLIN, J. A. 1991. The effects of reproduction and dispersal on the population structure of a freshwater ostracod. Ph.D Thesis, University of Wollongong, Australia.

CHAPLIN, J. A. 1992. Variation in the mode of reproduction among individuals of the ostracod Candonocypris novaezelandiae. Heredity, 68, 411-424.

CHAPLIN, J. A. AND AYRE, D. J. 1989. Genetic evidence of variation in the contributions of sexual and asexual reproduction to populations of the freshwater ostracod Candonocypris novaezelandiae. Freshwater Biol., 22, 275-284.

CUellar, o. 1977. Animal parthenogenesis. Science, 197, 837-843.

CURIE-COHEN, M. 1982. Estimates of inbreeding in a natural population: a comparison of sampling properties. Genetics, 100, 339-358.

DE DECKKER, P. 1981. Ostracoda from Australian inland waters: notes on taxonomy and ecology. Proc. R. Soc. Vic., 93, 45-83.

DE DECKKER, P. AND WILliams, w. D. 1988. Physio-chemical limnology of eleven, mostly saline permanent lakes in western Victoria, Australia. Hydrobiologia, 162, 275-286.

GLESENER, R. R. AND TILMAN, D. 1978. Sexuality and the components of environmental uncertainty: clues from geographic parthenogenesis in terrestrial animals. $\mathrm{Am}$. Nat., 112, 659-673.

HARTEN, D. VAN. 1983. Resource competition as a possible cause of sex ratio in benthic ostracods. In: Maddocks, R. F. (ed.) Applications of Ostracoda, University of Houston Geosc., Houston, pp. 568-580.

HAVEL, J. E., HEBERT, P. D. N. AND DELORME, L. D. 1990. Genetics of sexual Ostracoda from a low Arctic site. J. Evol. Biol., 3, 65-84.
HEBERT, P. D. N., WARD, R. D. AND WEIDER, L. J. 1988. Clonaldiversity patterns and breeding-system variation in Daphnia pulex, an asexual-sexual complex. Evolution, 42, 147-159.

HENDERSON, P. A. 1990. Freshwater Ostracods. Universal Book Services, The Netherlands.

Hughes, R. N. 1989. A Functional Biology of Clonal Animals. Chapman and Hall, London.

HURST, L. D., HAMILTON, W. D. AND LADLE, R. J. 1992. Covert sex. T.R.E.E., 7, 144-145.

HUSSAINY, S. U. 1969. Description of the male of Candonocypris assimilis G. O. Sars 1894 (Cypridae, Ostracoda). Proc. R. Soc. Vic., 82, 305-307.

JAENIKE, J. AND SELANDER, R. K. 1979. Evolution and ecology of parthenogenesis in earthworms. Am. Zool., 19, 729-73.

LYNCH, M. 1984. Destabilizing hybridization, general-purpose genotypes, and geographic parthenogenesis. Q. Rev. Biol., 59, 257-290.

MaYnard Smith, J. 1978. The Evolution of Sex. Cambridge University Press, London.

MCKENZIE, K. G. 1971. Palaeozoogeography of freshwater Ostracoda. In: Oertli H. J. (ed.) Paléoécologie des Ostracodes. Bull. Centre Rech. Pau-SNP,4, 5 suppl., 207-237.

MICHAELS, H. J. AND BAZZAZ, F. A. 1986. Resource allocation and demography of sexual and apomictic Antennaria parlinii. Ecology, 67, 27-36.

MICHOD, R. E. AND LEvin, B. R. 1988. The Evolution of Sex: An Examination of Current Ideas. Sinauer Associates Inc, Sunderland, MA.

MOORE, w. S. 1975. Stability of small unisexual-bisexual populations of Poeciliopsis (Pisces: Poeciliidae). Ecology, 56, 791-808.

Stearns, s. C. 1987. The Evolution of Sex and its Consequences. Birkhäuser Verlag, Boston.

STODDART, J. A. 1983. A genotypic diversity measure. J. Heredity, 74, 489-490.

STODDART, J. A. AND TAYLOR, J. F. 1988. Genotypic diversity: Estimation and prediction. Genetics, 118, 705-711.

TETART, J. 1975. Recherches sur la reproduction et l'ecologie de quelques Ostracodes Cyprididae. Ph.D. Thesis, USM Grenoble.

TIMMS, B. V. 1980a. The benthos of Australian lakes. In: Williams, W. D. (ed.) An Ecological Basis for Water Resource Management, Australian National University Press, Canberra, pp. 23-39.

Timms, B. v. 1980b. Farm dams. In: Williams, W. D. (ed.) An Ecological Basis for Water Resource Management, Australian National University Press, Canberra, pp. 345-359.

williams, G. C. 1975. Sex and Evolution. Princeton University Press, New Jersey. 